\title{
Antipsychotic-Like Actions of the Satiety Peptide, Amylin, in Ventral Striatal Regions Marked by Overlapping Calcitonin Receptor and RAMP-1 Gene Expression
}

\author{
Sarah K. Baisley, ${ }^{1}$ Quentin Z. Bremer, ${ }^{2}$ Vaishali P. Bakshi, ${ }^{1,2}$ and Brian A. Baldo ${ }^{1,2}$ \\ ${ }^{1}$ Neuroscience Training Program, University of Wisconsin-Madison, Medical Sciences Center, Madison, Wisconsin 53706, and ${ }^{2}$ Department of Psychiatry, \\ University of Wisconsin-Madison, Wisconsin 53719
}

\begin{abstract}
Amylin is a calcitonin-related peptide co-secreted with insulin, which produces satiety through brainstem-localized receptors; however, its effects in forebrain are poorly understood. The nucleus accumbens shell (AcbSh) exhibits among the densest concentrations of high-affinity amylin binding; nevertheless, these receptors have not been explored beyond one study showing dopamine antagonist-like effects of intra-Acb amylin on feeding and associated behavior (Baldo and Kelley, 2001). Here, we investigated whether intra-Acb amylin signaling modulates prepulse inhibition (PPI), a measure of sensorimotor gating deficient in several illnesses including schizophrenia. First, in situ hybridization revealed marked anatomical gradients for both receptor activity-modifying protein-1 (RAMP-1) and calcitonin receptor gene (CT-R) expression in striatum [coexpression of these genes yields a high-affinity amylin-1 receptor (AMY1-R)], with highest overlap in the medial AcbSh. Intra-AcbSh amylin infusions in rats (0, 30, and $100 \mathrm{ng})$ reversed amphetamine (AMPH)-induced PPI disruption without affecting baseline startle; dorsal striatal amylin infusions had no effect. Coinfusion of AC187 (20 $\mu \mathrm{g})$, an antagonist for AMY1-R, blocked the ability of amylin to normalize AMPH-induced PPI disruption, showing the specificity of AcbSh amylin effects to the AMY1-R. Intra-AcbSh AC187 on its own disrupted PPI in a haloperidol-reversible manner (0.1 mg/kg). Thus, AMY1-R may be a potential target for the development of putative antipsychotics or adjunct treatments that oppose metabolic side effects of current medications. Moreover, AMY1-Rs may represent a novel way to modulate activity preferentially in ventral versus dorsal striatum.
\end{abstract}

Key words: amylin receptor; dopamine; nucleus accumbens; RAMPs; schizophrenia; startle

\section{Introduction}

Some second-generation antipsychotics (SGA) used to treat schizophrenia produce adverse metabolic side effects including weight gain and hyperglycemia, which increase morbidity, and reduce treatment compliance (De Hert et al., 2012). While some drugs are relatively free of these problems, SGAs that lead to metabolic syndrome are still used clinically. Hence, there is a need to identify primary or adjunct treatments with antipsychotic effects that also oppose adverse metabolic consequences.

One candidate with such dual actions is amylin, a hormone coreleased with insulin (Castillo et al., 1995; Lutz, 2012). Amylin improves glycemic control, and produces satiety and weight loss (Roth et al., 2009; Singh-Franco et al., 2011), effects that could counteract SGA-related metabolic side effects.

Received May 23, 2013; revised Feb. 11, 2014; accepted Feb. 13, 2014.

Author contributions: B.A.B. and V.P.B. designed research; S.K.B. and Q.Z.B. performed research; S.K.B., Q.Z.B., V.P.B., and B.A.B. analyzed data; B.A.B. wrote the paper.

This work was supported by MH093824 (B.A.B., V.P.B.) and T32 GM007507 (S.K.B.). Facilities and procedures complied with animal use and care guidelines from the National Institutes of Health and were approved by the Institutional Animal Care and Use Committee of the University of Wisconsin.

The authors declare no competing financial interests.

Correspondence should be addressed to Brian A. Baldo, PhD, Department of Psychiatry, UWSMPH, 6001 Research Park Boulevard, Madison, WI 53719. E-mail: babaldo@wisc.edu.

DOI:10.1523/JNEUROSCI.2260-13.2014

Copyright $\odot 2014$ the authors $\quad 0270-6474 / 14 / 344318-08 \$ 15.00 / 0$
The distribution of CNS binding suggests that amylin could target regions that mediate antipsychotic effects. Among the densest sites of amylin binding in the entire brain is the nucleus accumbens shell (AcbSh; Beaumont et al., 1993; Sexton et al., 1994; van Rossum et al., 1994; Christopoulos et al., 1995), which modulates numerous schizophrenia-related processes including prepulse inhibition (PPI). The only study of intra-Acb amylin actions showed that amylin decreased exploratory activity and hunger-driven feeding (Baldo and Kelley, 2001); the activity suppression resembled functional dopamine (DA) antagonism. Because successful antipsychotics act partly through D2 receptor blockade (Boyd and Mailman, 2012), stimulation of AcbSh-localized amylin receptors may represent a novel means of producing antipsychotic-like effects.

Amylin receptors are complexes of calcitonin receptor (CT-R) and calcitonin-like receptor (CL-R) genes in conjunction with three identified receptor activity modifying proteins (RAMPs 1-3), which modulate CT-R and CL-R affinity (Young, 2005; Sexton et al., 2006); these are part of the GPCR receptor family. Combination of CT-R with RAMP-1 produces the receptor AMY1-R, whose affinity profile matches that of the high-affinity binding found in the AcbSh (Aiyar et al., 1995; Cristopoulos et al., 1999; Poyner et al., 2002). AMY1-R binding is largely absent from 
regions outside of AcbSh (i.e., lateral Acb core and dorsal striatum; Sexton et al., 1994; van Rossum et al., 1994), suggesting that AMY1-R may be a substrate for modulating activity specifically within AcbSh.

Here, we tested effects of intra-AcbSh AMY1-R agonism and antagonism on basal and disrupted (by the psychotomimetic amphetamine, AMPH) PPI. PPI deficits are considered an endophenotype for schizophrenia because they presumably reflect the sensorimotor gating abnormalities of schizophrenia; reversal of PPI deficits is a well validated tool for identifying drugs with antipsychotic efficacy, and is modulated in part through AcbSh (Braff and Light, 2004; Geyer, 2006; Swerdlow et al., 2008). We also obtained detailed striatal mappings of all amylin receptorfamily genes to delineate areas with densest CT-R/RAMP-1 coexpression and align these regions with markers that differentiate Acb compartments (Zahm and Heimer, 1993). Amylin reversed AMPH-induced PPI disruptions in the medial AcbSh, where there is the highest overlap of CT-R/RAMP-1, but had no effects in dorsal striatum, which showed very limited expression of AMY1-R genes. AMY1-R antagonism caused haloperidolreversible PPI disruptions. Hence, AMY1-R could be a viable target for developing antipsychotic-like drugs that oppose adverse metabolic side effects, and may also represent an important target for regulating AcbSh (DA) activity in an anatomically selective manner.

\section{Materials and Methods}

Subjects. Fifty-one pair-housed male Sprague Dawley rats (300-400 g; Harlan) were in clear cages in a temperature-controlled vivarium (lights on from 0700 to $1900 \mathrm{~h}$ ). All experiments except Experiment 3 were conducted between 1000 and $1500 \mathrm{~h}$; Experiment 3 was conducted between 2100 and $0000 \mathrm{~h}$. Facilities and procedures complied with animal use and care guidelines from the National Institutes of Health, and were approved by the Institutional Animal Care and Use Committee of the University of Wisconsin.

Surgery and drugs. Rats were anesthetized with isoflurane, and bilateral guide cannulae were implanted into either AcbSh (coordinates in millimeters from bregma with nosebar at $+5 \mathrm{~mm}$ : +3.2 anteroposterior (AP); \pm 1.0 lateromedial (LM); -5.2 dorsoventral (DV) or dorsal striatum (DS; nosebar at $-3.3 \mathrm{~mm}$ : $+1.6 \mathrm{AP}$; $\pm 2.4 \mathrm{LM}$; $-1.7 \mathrm{DV})$. Injectors extended $2.5 \mathrm{~mm}$ beyond the guide cannulae. Amylin (Bachem) and AMPH (Sigma) were dissolved in sterile isotonic saline, and AC187 (Tocris Bioscience) in sterile $\mathrm{dH}_{2} \mathrm{O}$. Postoperative recovery was 7-10 d with daily health checks.

Startle and PPI testing. Startle chambers (San Diego Instruments) consisted of Plexiglas cylinders within sound-attenuated cabinets; cylinders' piezoelectric units detected vibrations and via computer interface provided measures of startle magnitude. Whole-body startle responses were recorded for each $120 \mathrm{~dB}$ white noise burst ( $40 \mathrm{~ms}$; "pulse") that was either alone or preceded $100 \mathrm{~ms}$ by "prepulses" (20 ms) 3, 9, or $15 \mathrm{~dB}$ above background noise ( $65 \mathrm{~dB}$ ), and for no-stimulus trials (only background noise). Each trial type occurred 16 times in pseudorandom order. Startle magnitude $=$ average of pulse-alone trials during this segment of the session, and PPI for each prepulse intensity was a percentage score: $\% \mathrm{PPI}=100-\{[($ startle for prepulse + pulse trial $) /($ startle for pulse alone trial) $] \times 100\}$. Four pulse-alones also occurred at the beginning and end of the session to ensure stable startle magnitude during the PPI portion of the session (Geyer et al., 1990). Details are in Alsene et al. (2011).

In situ hybridization. Twenty micrometer sections (five sequential sets of slices for each rat) were processed for in situ hybridization (probes for RAMP-1, RAMP-2, RAMP-3, CT-R, and CL-R) using identical methods to Schochet et al. (2008), with minor modifications: PBS for initial washes, and washes immediately following acetylation with $1 \times$ Trisbuffered saline. Overnight hybridization with $150 \mu \mathrm{l}$ of [10,000 Cts/ $\mu \mathrm{l}]$ ${ }^{35} \mathrm{~S}$-labeled antisense riboprobe was in hybridization buffer (10 $\mu \mathrm{M}$ Tris,
$1 \mu \mathrm{M}$ EDTA, $0.3 \mathrm{M} \mathrm{NaCl}, 1 \times$ Denhardt's, $50 \%$ formamide, $10 \%$ dextran sulfate, $500 \mu \mathrm{g} / \mathrm{ml}$ tRNA, $50 \mathrm{~mm}$ dithiothreitol, DTT). Then, slides were washed twice in $4 \times$ saline-sodium citrate solution containing $2 \mathrm{~mm}$ DTT, then incubated for $30 \mathrm{~min}$ in $20 \mu \mathrm{g} / \mathrm{ml}$ RNaseA in $10 \mathrm{~mm}$ Tris- $\mathrm{HCl}$, $0.5 \mathrm{M} \mathrm{NaCl}, \mathrm{pH} 8.0$, at $37^{\circ} \mathrm{C}$.

After exposure to PhosphorImager screens (GE Healthcare; 4-23 d), depending upon signal intensity, screens were scanned on a Typhoon scanner, and quantification of average optical density was performed using ImageQuant 5.2 software (Molecular Dynamics). Some sections with RAMP-1 or CT-R probes underwent further processing for photographic emulsion autoradiography, with light-sensitive processing steps in a darkroom. Briefly, slides were dipped in heated $\left(44^{\circ} \mathrm{C}\right)$ liquid NTB-2 photographic emulsion (Kodak) and then air dried for $2 \mathrm{~h}$ before being covered with tinfoil and stored in a darkroom. Due to strength of labeling, RAMP-1 slides were exposed to emulsion for $3 \mathrm{~d}$, with all others for $17 \mathrm{~d}$. Afterward, slides were brought to room temperature, developed for 5 min with D19 developer, washed with $32^{\circ} \mathrm{C}$ water for $30 \mathrm{~s}$, exposed to fixer (Kodak) for $5 \mathrm{~min}$, washed with $32^{\circ} \mathrm{C}$ water for $15 \mathrm{~min}$, and air dried.

Experimental design. Six experiments using separate rats were conducted with counterbalanced within-subjects designs; $>2-3 \mathrm{~d}$ separated consecutive tests, and intracranial microinfusion volumes were $0.5 \mu \mathrm{l} /$ side.

Experiment 1. Six naive rats were anesthetized with isoflurane, decapitated, and brains were flash frozen and stored at $-80^{\circ} \mathrm{C}$ until cryostat sectioning and in situ hybridization for amylin receptor genes.

Experiment 2. Rats received intra-AcbSh amylin ( $0 \mathrm{ng}$ or $30 \mathrm{ng} ; \mathrm{N}=6$ ) immediately before AMPH ( $0 \mathrm{mg} / \mathrm{kg}$ or $1.75 \mathrm{mg} / \mathrm{kg}$, s.c.), and $5 \mathrm{~min}$ later were tested for PPI.

Experiment 3. Identical to Experiment 2, but rats instead received a higher dose of intra-AcbSh amylin ( $0 \mathrm{ng}$ or $100 \mathrm{ng} ; \mathrm{N}=6-8$ /group).

Experiment 4. Rats $(N=7)$ received haloperidol $(0 \mathrm{mg} / \mathrm{kg}$ or $0.1 \mathrm{mg} /$ $\mathrm{kg}$, s.c.) $15 \mathrm{~min}$ before intra-AcbSh infusions of the AMY1-R antagonist AC187 (0 $\mu \mathrm{g}$ or $20 \mu \mathrm{g}$; Hay et al., 2005) immediately before PPI testing. This experiment occurred during the dark cycle when endogenous release of amylin is highest to assess AC187 effects when basal signaling at AMY1-R would be greatest.

Experiment 5. Same as Experiment 3, but with amylin (0 ng or $100 \mathrm{ng}$ ) infusions into DS $(N=8)$.

Experiment 6. Identical to Experiment 5, but instead with a lower and higher dose of amylin into DS (0 ng, $30 \mathrm{ng}$, or $300 \mathrm{ng} ;=10$ ).

Data analysis. Multifactor ANOVAs were used for in situ hybridization data (striatal level $\times$ region of interest (ROI) for each gene), PPI (pretreatment $\times$ treatment $\times$ prepulse intensity), startle (pretreatment $\times$ treatment); significant main effects or interactions were followed by Bonferroni-adjusted $t$ tests and Tukey's post hocs. Experimenters blind to data and treatments confirmed injector placements in Nissl-stained sections; final sample sizes exclude rats with placements outside of target sites.

\section{Results}

All PPI experiments showed significant main effects of prepulse intensity, a standard parametric feature of PPI in which larger prepulse intensities elicit greater PPI (Alsene et al., 2011); for brevity, this is not repeated throughout. Also, there were no main effects of treatments or interactions between treatments on startle habituation (the normal reduction in startle magnitude that occurs in response to the pulse-alone trials across the entire session).

\section{Highest RAMP-1/CT-R gene expression overlap is in medial AcbSh}

Previous whole-brain surveys evaluated RAMPs and CT-Rs separately, with just one to two striatal sections not in anatomical registration across studies (Nakamoto et al., 2000; Oliver et al., 2001; Ueda et al., 2001; Becskei et al., 2004; Lee et al., 2008). We therefore conducted a systematic in situ hybridization study of all RAMPs and 

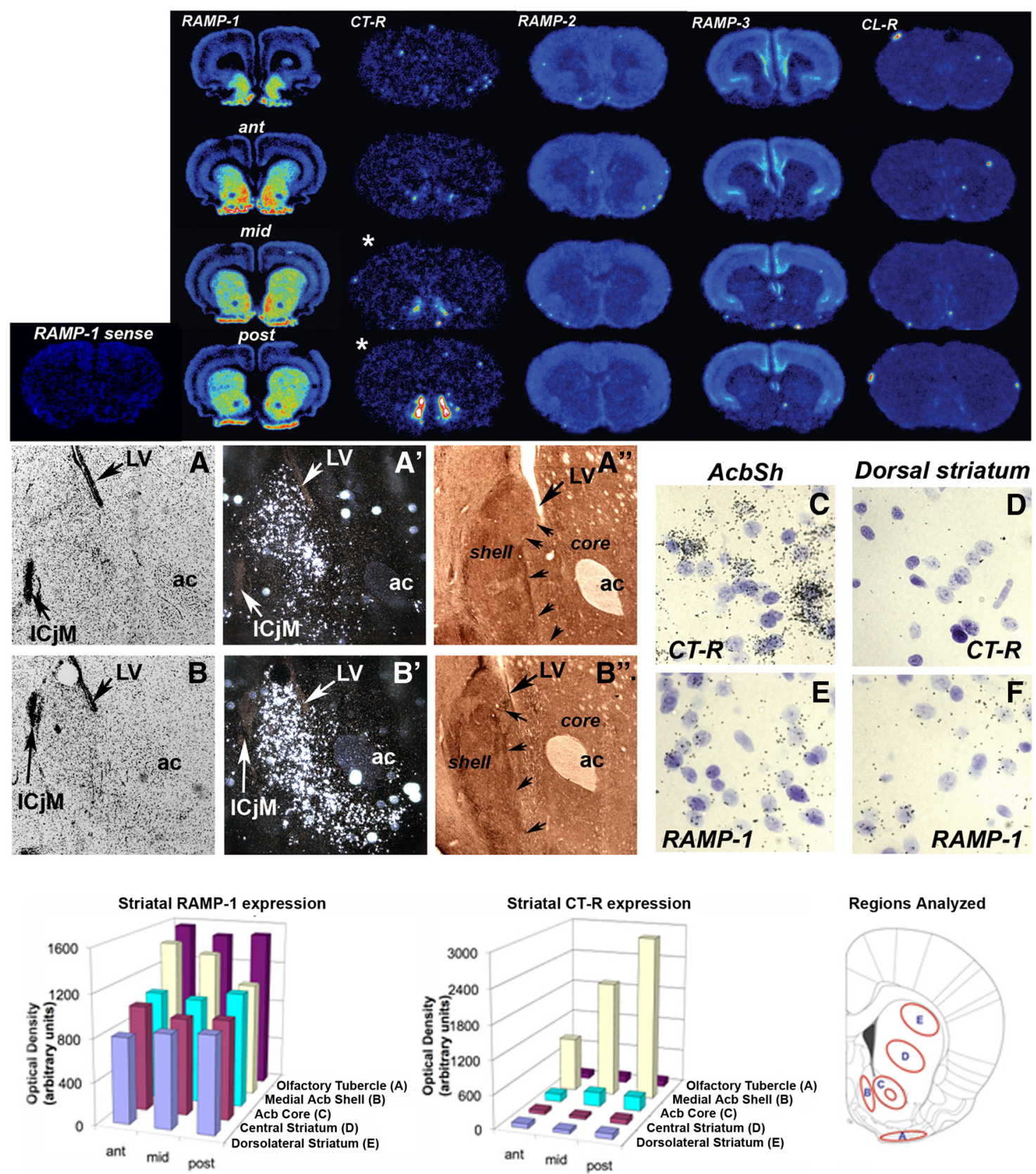

Figure 1. Top, Pseudocolor images showing hybridization of probes for RAMPs $1-3, C T R$, and CL-R in striatum $(N=6)$. Warmer colors indicate greater labeling; white shows highest intensity. A section hybridized with the sense probe for RAMP-1 is included, showing a lack of nonspecific labeling. Middle, Sections hybridized with CT-R probe, processed for photographic emulsion autoradiography (with Nissl counterstain) at two AP levels (see asterisks in the top). $\boldsymbol{A}, \boldsymbol{B}$, Bright-field images showing the Nissl staining. $\boldsymbol{A}^{\prime}$ and $\boldsymbol{B}^{\prime}$, Dark-field images of the same field of view, with silver grains showing (T-R labeling. $\boldsymbol{A}^{\prime \prime}$ and $\boldsymbol{B}^{\prime \prime}$, In-register sections processed for substance P immunoreactivity. Small arrowheads depict the core-shell boundary. C-F, Bright-field images of silver grains (appearing as black specks) for (T-R and RAMP-1 labeling and Nissl-stained cells (appearing purple). Bottom, Bar graphs depicting signal intensity of RAMP-1 and CT-R at multiple striatal levels. Ant, mid, and post correspond to levels shown in the top. ac, anterior commissure; LV, lateral ventricle; ICjM, Island of Calleja, major island.

the two calcitonin receptor-subtype genes in serial striatal sections, focusing on levels through Acb. Gene expression analyses were conducted using five ROIs along DV and ML gradients through striatum and allied regions. ROIs were placed in DS, central striatum, nucleus accumbens core (AcbC), AcbSh, and olfactory tubercle (OT; Fig. 1). Mean optical density values within ROIs were analyzed at three AP levels of striatum, with ROIs from each hemisphere averaged. For RAMP-1, ANOVA showed significant differences among the ROIs across the three anatomical levels $(\mathrm{ROI} \times$ level interaction, $\left.F_{(8,45)}=2.5 ; p=0.023\right)$. Expression (collapsed across AP level) was highest in OT compared with all other regions ( $p$ s $<0.001$ ), and expression in medial AcbSh was higher than all other regions except OT $(p s<0.001)$. AcbC showed higher expression than DS $(p=$ 0.009). Analyses at each AP level revealed that the most posterior AcbSh level showed significantly less RAMP-1 expression compared with the anterior $(p<0.001)$ and middle $(p=0.008)$. For CT-R, gene expression was limited almost exclusively to AcbSh (ROI $\times$ level interaction: $\left.F_{(8,15)}=6.6 ; p<0.001\right)$. Emulsion autoradiography confirmed the strong signal in medial AcbSh (overlapping with zones of strong substance P immunoreactivity, in side-by-side com- 

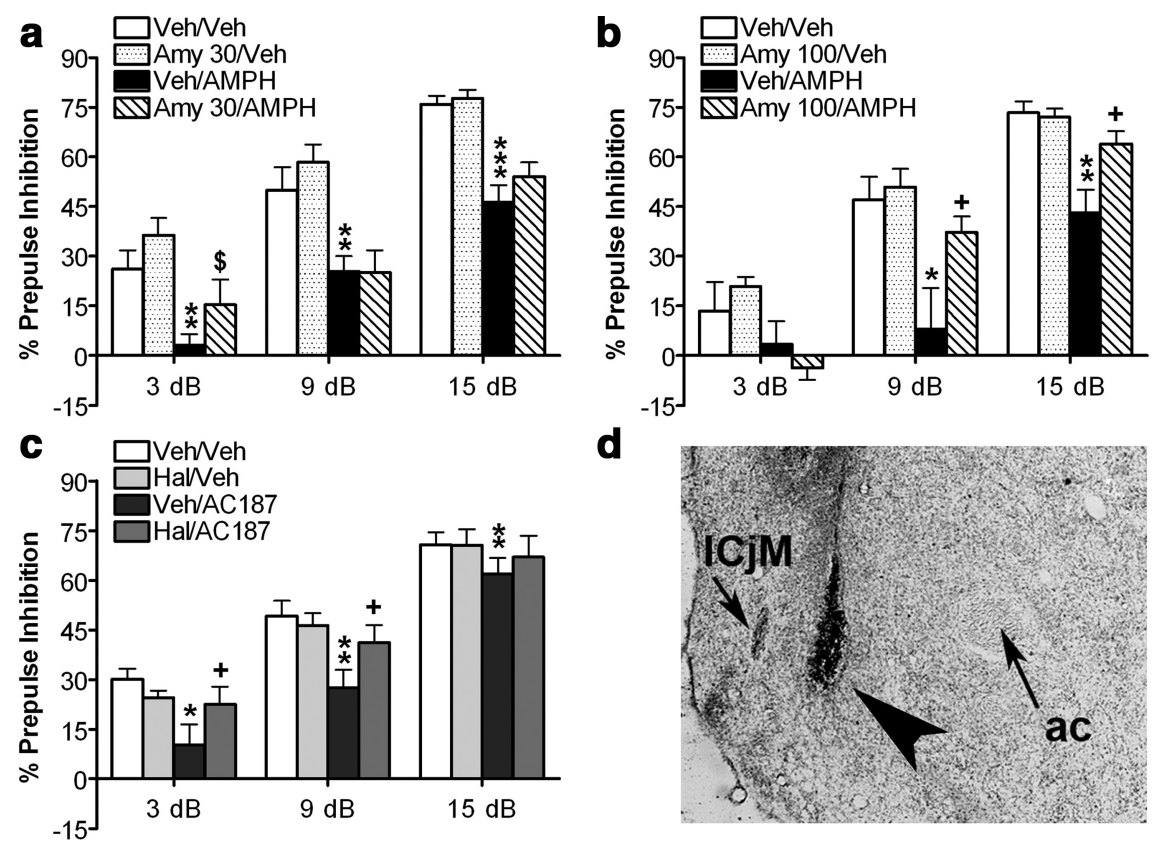

Figure 2. PPl effects of AMPH (1.75 mg/kg, s.c.) and intra-AcbSh amylin (Amy). $\boldsymbol{a}$, Amylin: $30 \mathrm{ng} / 0.5 \mu \mathrm{l}(\mathrm{N}=6)$ ). $\boldsymbol{b}$, Amylin: 100 $\mathrm{ng} / 0.5 \mu \mathrm{l}(N=6-8)$. c, Haloperidol (Hal; $0.1 \mathrm{mg} / \mathrm{kg})$ and intra-AcbSh AC187 $(20 \mu \mathrm{g} / 0.5 \mu \mathrm{l} ; N=7)$. d, Large arrows show representative injector tips within AcbSh. ac, anterior commissure; ICjM, Island of Calleja. Prepulse intensities are decibels above background. Values represent mean $\pm S E M ;{ }^{*} p<0.05,{ }^{* *} p<0.01$ versus corresponding vehicle/vehicle (Veh/Veh) condition, ${ }^{+} p<0.05$ versus Veh/AMPH, $\$$ denotes a trend $(p<0.07)$ versus Veh/AMPH.

parisons with in-register sections; Fig. 1). At middle and posterior levels, some signal was seen in medial aspects of AcbC, although labeling was still strongest in AcbSh. As a control, labeling with a RAMP-1 sense probe was done, but no signal was detected (Fig. 1), indicating that expression patterns with the aforementioned antisense probes were not from nonspecific binding.

\section{Intra-AcbSh amylin reverses AMPH-induced PPI deficits via AMY1-R}

A main effect of AMPH on PPI was found in Experiment 2 $\left(F_{(1,5)}=25.6, p<0.01\right)$ and Experiment $3\left(F_{(1,12)}=28.9, p<\right.$ $0.001)$. Post hoc analyses showed reductions in PPI by AMPH at all prepulse intensities (Fig. $2 ; p<0.05-p<0.001$ ). Neither dose of amylin affected PPI on its own (30 ng: $F_{(1,5)}=3.3$, NS; 100 ng: $\left.F_{(1,12)}=2.9, \mathrm{NS}\right)$, but a pretreatment $\times$ treatment $\times$ prepulse-intensity interaction for the higher dose $\left(F_{(2,24)}=4.9\right.$, $p<0.02)$ that was followed by post hocs indicated that amylin significantly improved PPI in AMPH-treated rats $(p<0.05)$ at multiple prepulse intensities (Fig. $2 b$ ). Similar comparison of means in the low-dose experiment also indicated that at the $3 \mathrm{~dB}$ prepulse intensity, there was a strong trend $(p<0.07)$ for higher PPI levels in the Amy/AMPH versus the Veh/AMPH condition (Fig. 2a). Therefore, intra-AcbSh amylin, without altering basal PPI on its own, was found to partially reverse PPI deficits that were induced by systemic AMPH.

To ascertain the specificity of this amylin reversal to actions at the AMY1-R, an additional study was conducted in which a mixture of amylin (100 ng) plus the highly selective AMY1-R antagonist AC187 (20 $\mu$ g; Hay et al., 2005) was infused into AcbSh before systemic AMPH $(1.75 \mathrm{mg} / \mathrm{kg})$. The reasoning was that if AC187 could prevent the PPI-restorative effect of amylin, then it could be concluded that amylin's ability to restore PPI in AMPHtreated rats is due to actions at the AMY1-R and not from nonspecific effects. In this study, mean composite PPI values (PPI averaged across the three prepulse intensities since no significant interaction with this variable was seen) were as follows: vehicle/vehicle $=49.17 \pm 5.2$; vehicle/ $\mathrm{AMPH}=23.5 \pm 2.4$; amylin and AC187 mixture/vehicle $=52.9 \pm 9.2$; amylin and AC187 mixture/AMPH $=26.4 \pm 7.7$. As before, there was a main effect of treatment showing a significant disruption of PPI by AMPH $\left(F_{(1,4)}=9.3, p<0.05\right)$. The amylin and AC187 mixture had no effect on PPI $\left(F_{(1,4)}=0.3\right.$, NS), nor was a pretreatment $\times$ treatment interaction seen $\left(F_{(1,4)}=0.008\right.$, NS $)$, indicating that the mixture did not alter the AMPH-induced PPI deficit. Therefore, intra-AcbSh infusion of the selective antagonist for the AMY1-R (AC187) abolished amylin's ability to reverse the AMPH-induced PPI deficit, suggesting that even at the $100 \mathrm{ng}$ dose, amylin's PPI-restorative ability arises from actions at the AMY1-R.

As one additional control, we examined the effects of this dose of AC187 on its own, to confirm that the above null result with the mixture infusion was not due to individual AC187 effects on PPI. Thus, separate rats were tested with intraAcbSh infusions of AC187 (0 or $20 \mu \mathrm{g}$ ) immediately before PPI testing $(N=7)$ at the same time of day as the previous studies. No main effect of AC187 was seen on PPI $\left(F_{(1,6)}=0.6, \mathrm{NS}\right)$ and there was no interaction of treatment with prepulse intensity $\left(F_{(2,12)}=0.9\right.$, NS). The mean composite PPI values were as follows: $41.03 \pm 4.6$ for vehicle, and $45.61 \pm 5.0$ for AC187. Hence, during the light cycle, AC187 does not affect PPI on its own, but does completely prevent the PPI-restorative actions of $100 \mathrm{ng}$ of amylin in the AcbSh. Fig. $2 d$ shows a representative injector placement in AcbSh.

\section{During presumptive high endogenous amylin levels, AC187 disrupts PPI in a haloperidol-reversible manner}

While the previous study indicated no effect of AC187 on PPI during the daytime, the light portion of the light/dark cycle may be characterized by relatively lower endogenous amylin tone, and thus antagonism of AMY1-R in AcbSh at that time point may have a smaller effect (since there is less endogenous ligand to block). Several reports indicate that endogenous amylin release, which occurs with insulin release from pancreatic cells, is highest postprandially (Ogawa et al., 1990; Arnelo et al., 1998; Qi et al., 2010). Given that in rats, the dark portion of the light/dark cycle is when the highest levels of feeding occur, it is possible that endogenous amylin tone would be higher during the dark phase.

Hence, to maximize chances of detecting an AC187 effect, an experiment was run during the dark phase, and did reveal a significant main effect of AC187 on PPI $\left(F_{(1,6)}=20.3, p<0.004\right)$, with post hocs indicating that AC187 disrupted PPI at all prepulse intensities $(p<0.05-p<0.01$; Fig. $2 c)$. Haloperidol on its own had no effect $\left(F_{(1,6)}=1.6\right.$, NS), but did interact with AC187 $\left(F_{(1,6)}=6.9, p<0.039\right)$. Post hocs showed that haloperidol significantly improved PPI in AC187-treated rats $(p<$ 0.05 ) at multiple prepulse intensities (Fig. $2 c$ ). Thus, blocking AMY1-R at a time of presumptive high endogenous amylin tone produces a deficit in PPI that is reversed by DA receptor 
antagonism, suggesting that AcbSh AMY1-R signaling regulates PPI in part by modifying DA actions in AcbSh.

\section{Amylin in DS has no effects}

To determine the anatomical specificity of the amylin reversal of AMPH-induced PPI deficits, a wide dose range of amylin was evaluated in neighboring DS. Because no significant interactions were found with prepulse intensity and any other factor, these data are presented as composite PPI scores (PPI values averaged across the three prepulse intensities). AMPH disrupted PPI, indicated by significant main effects of treatment $\left(F_{(1,7)}=9.2, p<0.02\right.$ and $\left.F_{(1,9)}=41.2, p<0.001\right)$ and subsequent post hocs $(p<0.05)$ in these exper-

iments (Fig $3 a)$. Neither $100 \mathrm{ng}$ amylin $\left(F_{(1,7)}=0.05\right.$, NS) nor 30 and $300 \mathrm{ng}$ doses $\left(F_{(2,18)}=0.5, \mathrm{NS}\right)$ in DS produced main effects on PPI. Amylin into DS also did not interact with AMPH treatment at any dose $\left(F_{(1,7)}=0.2, \mathrm{NS} ; F_{(2,18)}=0.9\right.$, NS), indicating that it did not change AMPH-induced PPI deficits. For presentation simplicity, Veh//Veh and Veh/ AMPH bars were averaged across the two experiments, since there was no significant difference between them $\left(F_{(1,16)}=0.7\right.$, NS), and all DS PPI results are shown together in Fig. $3 a$, with a representative DS injector placement in Fig. $3 b$.

\section{AMY1-R manipulations failed to alter startle}

In every AMPH experiment, there was a significant main effect of treatment on baseline startle, with AMPH lowering this measure (Table 1). No effects of other drugs or any interactions with AMPH were seen. Therefore, AMPH reduced baseline startle (an effect that we and others have seen previously; Alsene et al., 2010), but in contrast to the PPI profile, the startle-reduction effect of AMPH was not reversed by stimulating AMY1-R in AcbSh, suggesting that the PPI-ameliorative effects of AcbSh amylin are specific to sensorimotor gating and not just an artifact of altering baseline startle responses.

\section{Discussion}

A systematic striatal in situ hybridization mapping showed significant AP and DV intrastriatal gradients of CT-R and RAMP-1 gene expression (the molecular components of the high-affinity AMY1-R), with an overlapping zone in a circumscribed area of the medial AcbSh, where infusion of amylin-active compounds modulated PPI. Intra-AcbSh amylin reversed AMPH-induced PPI deficits; coinfusion of amylin plus the selective AMY1-R antagonist AC187 completely prevented the amylin-induced reversal, indicating specificity of this phenomenon to the AMY1-R. Furthermore, blockade of AMY1-R with AC187 during the dark cycle (a period of presumptive high endogenous amylin tone) produced PPI disruptions that were reversible by haloperidol (DA antagonist). These effects were independent of baseline startle alterations, suggesting that results cannot be explained simply as artifacts of baseline startle changes. To our knowledge, this is the first demonstration that endogenous amylin signaling specifically in the ventral striatum regulates schizophrenia-like information-processing deficits, likely through the modulation of dopaminergic activity.

To date, central amylin actions have been studied almost exclusively with regard to feeding and energy-balance regulation

\section{Table 1. Startle magnitude \pm SEM by experiment}

\begin{tabular}{|c|c|c|c|}
\hline Experiment & F-ratio & Treatment & Startle \\
\hline \multirow[t]{4}{*}{2} & \multirow{4}{*}{$F_{(1,5)}=83.5, p<0.001$} & Veh/Veh & $322 \pm 37$ \\
\hline & & Amy 30/Veh & $394 \pm 33$ \\
\hline & & Veh/AMPH & $114 \pm 11^{* *}$ \\
\hline & & Amy 30/AMPH & $113 \pm 23^{* *}$ \\
\hline \multirow[t]{4}{*}{3} & \multirow{4}{*}{$F_{(1,12)}=12.3, p<0.004$} & Veh/Veh & $449 \pm 135$ \\
\hline & & Amy 100/Veh & $447 \pm 89$ \\
\hline & & Veh/AMPH & $191 \pm 48^{*}$ \\
\hline & & Amy 100/AMPH & $270 \pm 45^{*}$ \\
\hline \multirow[t]{4}{*}{4} & \multirow{4}{*}{$\begin{array}{l}\text { No significant main effects } \\
\text { or interactions }\end{array}$} & Veh/Veh & $578 \pm 76$ \\
\hline & & Hal/Veh & $595 \pm 55$ \\
\hline & & Veh/AC187 & $517 \pm 70$ \\
\hline & & $\mathrm{Hal} / \mathrm{AC} 187$ & $601 \pm 60$ \\
\hline \multirow[t]{7}{*}{5 and 6} & $F_{(1,7)}=27.1, p<0.01$ & Veh/Veh & $453 \pm 57$ \\
\hline & \multirow{6}{*}{$F_{(1,9)}=60.7, p<0.0001$} & Amy 30/Veh & $354 \pm 34$ \\
\hline & & Amy 100/Veh & $561 \pm 76$ \\
\hline & & Amy 300/Veh & $334 \pm 30$ \\
\hline & & Veh/AMPH & $219 \pm 30^{* *}$ \\
\hline & & Amy 30/AMPH & $192 \pm 22^{* * *}$ \\
\hline & & Amy 300/AMPH & $203 \pm 34^{* *}$ \\
\hline \multirow{4}{*}{$\begin{array}{l}\text { Amylin/AC187 } \\
\text { cocktail study }\end{array}$} & \multirow[t]{4}{*}{$F_{(1,4)}=64.1, p<0.01$} & Veh/Veh & $339 \pm 41$ \\
\hline & & Cocktail/Veh & $442 \pm 63$ \\
\hline & & Veh/AMPH & $114 \pm 14^{* *}$ \\
\hline & & Cocktail/AMPH & $191 \pm 34^{*}$ \\
\hline \multirow{2}{*}{$\begin{array}{l}\text { AC187 } \\
\text { daytime } \\
\text { study }\end{array}$} & \multirow{2}{*}{$\begin{array}{l}\text { No significant main effects } \\
\text { or interactions }\end{array}$} & Veh & $419 \pm 67$ \\
\hline & & AC187 & $407 \pm 58$ \\
\hline
\end{tabular}

Veh, Vehicle; Amy, Amylin (ng/0.5 $\mu$ l); AMPH, amphetamine (1.75 mg/kg); Hal, haloperidol (0.1 mg/kg);AC187, 20 $\mu \mathrm{g} / 0.5 \mu \mathrm{l} .{ }^{*} p<0.05$, ${ }^{* *} p<0.01,{ }^{* * *} p<0.001$, compared to corresponding Veh/Veh. Data from Experiments $4-5$ are combined, but statistical analyses were separate. F-ratios are for AMPH main effects. Ns $=6-10$.

(Castillo et al., 1995; Rushing et al., 2001; Lutz, 2012). Amylin is released peripherally with insulin from pancreatic $\beta$-cells, but acts centrally to produce satiety-like effects through neurons in the area postrema (AP) that trans-synaptically suppress hypothalamic feeding centers via a parabrachial relay (Potes et al., 2010; Lutz, 2012). Amylin also modulates feeding and body weight via actions in the medial basal hypothalamus and ventral tegmental area (VTA; Roth et al., 2008; Turek et al., 2010; Mietlicki-Baase et al., 2013). Beyond these sites, however, amylin's central effects are poorly understood, despite the fact that Acb exhibits among the highest density of amylin binding sites in the entire brain (Sexton et al., 1994; van Rossum et al., 1994). Only one prior study examined intra-Acb amylin actions, showing a suppressive effect of exogenously administered amylin on feeding and associated exploratory activity (Baldo and Kelley, 2001); however, this study did not assess the behavioral role of endogenous intra-Acb amylin signaling. 
The present demonstration of a psychotomimetic-like PPI disruption with intra-AcbSh infusions of the AMY1-R antagonist, AC187, reveals for the first time a behaviorally relevant amylin "tone" at the level of the telencephalon. The endogenous ligand is unknown, but likely candidates include peripherally released amylin (amylin crosses the blood-brain barrier to collect in striatum and other sites, with better brain penetrance than insulin; Banks and Kastin, 1998), or endogenous peptides of the amylin family, such as CGRP (van Rossum et al., 1997). Circadian fluctuations in endogenous amylin levels reaching the Acb could contribute to our finding that intra-Acb AC187 disrupts PPI during the dark cycle but not during the light cycle. Thus, amylin levels are highest postprandially (Butler et al., 1990; Young and Denaro, 1998), and feeding rates in rats are highest during the dark cycle. Previous studies showing similar diurnal differences in sensitivity to the anorectic effects of amylin are not inconsistent with this hypothesis (Lutz et al., 1995).

The reversal of the PPI-disruptive effect of intra-AcbSh AC187 by haloperidol suggests that amylin signaling in the Acb interacts with DA function. There is evidence for central amylindopamine interactions, although specific sites and mechanisms are unclear. For example, intraventricularly administered amylin reduces the effects of systemically administered DA agonists on locomotor activity and sexual behavior (Clementi et al., 1996, 1999); a D2 antagonist alters the satiety effect engendered by peripheral amylin, possibly via interactions in the nucleus tractus solitarii (Lutz et al., 2001); and amylin's feeding-inhibitory effects are augmented in D3-receptor knock-out mice (Benoit et al., 2003). The present finding that haloperidol reversed AC187's PPI-disruptive effect indicates that DA signaling contributes to behavioral changes induced by amylin receptor blockade at the level of the AcbSh. One explanation is that the interaction occurs at AMY1-Rs located postsynaptic to dopaminergic innervation, because CT-R and RAMP-1 mRNA is localized in AcbSh-suggesting that the receptors are produced in medium spiny striatal neurons. AMY1-R signaling may, for example, reduce DA receptor activity in Acb medium spiny neurons through membrane receptor-receptor interactions or intracellular signaling cascades; the net effect being that amylin blockade releases DA receptors from negative modulation and augments their responsiveness to endogenous DA release. This model would also predict that stimulation of AMY1-Rs with exogenously administered ligand would augment negative dopaminergic modulation, accounting for the antipsychotic-like actions of amylin seen here. Note that a postsynaptic locus of action in medium spiny neurons would also have implications for AMY1-R modulation of incoming glutamate signals, raising the possibility that amylin agonists may also effectively counteract the effects of PCP-type drugs.

Another mechanism for intrastriatal amylin action is suggested by the recent results of Mietlicki-Baase et al. (2013), who found evidence for RAMP-1 and CT-R gene expression in the VTA using qRT-PCR. Perhaps AMY-1 receptors are transported from VTA and expressed in dopaminergic nerve terminals within AcbSh, providing a potential substrate for presynaptic modulation of DA release by AMY-R signaling. Further studies are required to identify whether the primary locus of intra-Acb AMY1-R activity is presynaptic or postsynaptic to the DA innervation. Nevertheless, the present results are the first to suggest tonic modulation of DA activity by AMY1-R signaling within Acb.

As previously discussed, coexpression of RAMP-1 and CT-R yields the high-affinity AMY-1 subtype whose affinity profile for amylin and related peptides matches the high-affinity binding seen in the Acb (Poyner et al., 2002; Young, 2005). Whole-brain surveys (Nakamoto et al., 2000; Oliver et al., 2001; Ueda et al., 2001; Becskei et al., 2004; Lee et al., 2008) have reported the presence of RAMP-1 and CT-R mRNA in a limited number of striatal sections, with no analysis of gradients across striatal subregions. Here we extended prior results by showing a systematic mapping and semiquantitative analysis of these genes through multiple subregions at various rostrocaudal levels of striatum. We confirm that RAMP-1 and CT-R are the only amylinreceptor family genes present in striatum in high abundance, and moreover show a gradient of RAMP-1 gene expression, with highest levels in a restricted zone of medial AcbSh. Here it overlaps a remarkably circumscribed zone of intense CT-R expression. At rostral levels of the Acb, CT-R expression is seen almost exclusively in the medial shell, in register with the classic marker of the core-shell boundary, substance P (Zahm and Heimer, 1993). Progressing caudally, CT-R expression is still highest in the medial shell, although some labeling is also seen in medial sectors of the core. CT-R gene expression is almost completely absent from lateral parts of the core, and completely absent from DS.

Hence, the AMY1-R represents a substrate at which neural activity in the medial AcbSh, relative to the rest of striatum, can potentially be targeted with considerable precision. An interesting implication is that amylin-active agonists may represent adjunct treatments that potentiate antipsychotic actions in the ventral striatum but not DS, reducing the required antipsychotic dose and thereby limiting motoric or other side effects mediated in the DS. While high doses of amylin can reduce exploratory activity (Baldo and Kelley, 2001), the dose range required to ameliorate PPI deficits in the present study had no effect on baseline startle, which provides a concurrent measure of motor function. Beyond schizophrenia, the circumscribed distribution of AMY1-R gene components has implications for understanding the neurochemical modulation of behavioral processes mediated specifically by the medial shell, notably the enhancement of hedonic food reward (Peciña and Berridge, 2005).

The amylin analog, pramlintide (Symlin) reduces many deleterious metabolic processes such as weight gain, hyperglycemia, and insulin resistance, and in several studies shows promise as an anti-obesity drug (Singh-Franco et al., 2011; Roth et al., 2012). Although future work on PPI-modulatory effects of systemically administered amylin needs to be done, the present findings indicate that AMY1-R signaling in the ventral striatum is a functional locus for antipsychotic activity. Hence, AMY1-R-active drugs might not only oppose the metabolic side effects of certain SGAs, but also improve their antipsychotic efficacy. It would be interesting to see if Symlin would have utility either on its own or as an adjunct treatment for schizophrenia patients who suffer from metabolic side effects of otherwise beneficial antipsychotic drugs.

\section{References}

Aiyar N, Baker E, Martin J, Patel A, Stadel JM, Willette RN, Barone FC (1995) Differential calcitonin gene-related peptide (CGRP) and amylin binding sites in nucleus accumbens and lung: potential models for studying CGRP/amylin receptor subtypes. J Neurochem 65:11311138. Medline

Alsene KM, Fallace K, Bakshi VP (2010) Ventral striatal noradrenergic mechanisms contribute to sensorimotor gating deficits induced by amphetamine. Neuropsychopharmacology 35:2346-2356. CrossRef Medline 
Alsene KM, Rajbhandari AK, Ramaker MJ, Bakshi VP (2011) Discrete forebrain neuronal networks supporting noradrenergic regulation of sensorimotor gating. Neuropsychopharmacology 36:1003-1014. CrossRef Medline

Arnelo U, Reidelberger R, Adrian TE, Larsson J, Permert J (1998) Sufficiency of postprandial plasma levels of islet amyloid polypeptide for suppression of feeding in rats. Am J Physiol 275:R1537-R1542. Medline

Baldo BA, Kelley AE (2001) Amylin infusion into rat nucleus accumbens potently depresses motor activity and ingestive behavior. Am J Physiol Regul Integr Comp Physiol 281:R1232-R1242. Medline

Banks WA, Kastin AJ (1998) Differential permeability of the blood-brain barrier to two pancreatic peptides: insulin and amylin. Peptides 19:883889. CrossRef Medline

Beaumont K, Kenney MA, Young AA, Rink TJ (1993) High affinity amylin binding sites in rat brain. Mol Pharmacol 44:493-497. Medline

Becskei C, Riediger T, Zünd D, Wookey P, Lutz TA (2004) Immunohistochemical mapping of calcitonin receptors in the adult rat brain. Brain Res 1030:221-233. CrossRef Medline

Benoit SC, McQuade JA, Clegg DJ, Xu M, Rushing PA, Woods SC, Seeley RJ (2003) Altered feeding responses in mice with targeted disruption of the dopamine-3 receptor gene. Behav Neurosci 117:46-54. CrossRef Medline

Boyd KN, Mailman RB (2012) Dopamine receptor signaling and current and future antipsychotic drugs. Handb Exp Pharmacol 53-86. CrossRef Medline

Braff DL, Light GA (2004) Preattentional and attentional cognitive deficits as targets for treating schizophrenia. Psychopharmacology 174:75-85. Medline

Butler PC, Chou J, Carter WB, Wang YN, Bu BH, Chang D, Chang JK, Rizza RA (1990) Effects of meal ingestion on plasma amylin concentration in NIDDM and nondiabetic humans. Diabetes 39:752-756. CrossRef Medline

Castillo MJ, Scheen AJ, Lefèbvre PJ (1995) Amylin/islet amyloid polypeptide: biochemistry, physiology, patho-physiology. Diabete Metab 21:325. Medline

Christopoulos G, Paxinos G, Huang XF, Beaumont K, Toga AW, Sexton PM (1995) Comparative distribution of receptors for amylin and the related peptides calcitonin gene related peptide and calcitonin in rat and monkey brain. Can J Physiol Pharmacol 73:1037-1041. CrossRef Medline

Christopoulos G, Perry KJ, Morfis M, Tilakaratne N, Gao Y, Fraser NJ, Main MJ, Foord SM, Sexton PM (1999) Multiple amylin receptors arise from receptor activity-modifying protein interaction with the calcitonin receptor gene product. Mol Pharmacol 56:235-242. Medline

Clementi G, Valerio C, Emmi I, Prato A, Drago F (1996) Behavioral effects of amylin injected intracerebroventricularly in the rat. Peptides 17:589591. CrossRef Medline

Clementi G, Busa L, de Bernardis E, Prato A, Drago F (1999) Effects of centrally injected amylin on sexually behavior of male rats. Peptides 20 : 379-382. CrossRef Medline

De Hert M, Detraux J, van Winkel R, Yu W, Correll CU (2012) Metabolic and cardiovascular adverse effects associated with antipsychotic drugs. Nat Rev Endocrinol 8:114-126. CrossRef Medline

Geyer MA (2006) Are cross-species measures of sensorimotor gating useful for the discovery of procognitive cotreatments for schizophrenia? Dialogues Clin Neurosci 8:9-16. Medline

Geyer MA, Swerdlow NR, Mansbach RS, Braff DL (1990) Startle response models of sensorimotor gating and habituation deficits in schizophrenia. Brain Res Bull 25:485-498. CrossRef Medline

Hay DL, Christopoulos G, Christopoulos A, Poyner DR, Sexton PM (2005) Pharmacological discrimination of calcitonin receptor: receptor activitymodifying protein complexes. Mol Pharmacol 67:1655-1665. CrossRef Medline

Lee J, Gomez-Ramirez J, Johnston TH, Visanji N, Brotchie JM (2008) Receptoractivity modifying protein 1 expression is increased in the striatum following repeated L-DOPA administration in a 6-hydroxydopamine lesioned rat model of Parkinson's disease. Synapse 62:310-313. CrossRef Medline

Lutz TA (2012) Control of energy homeostasis by amylin. Cell Mol Life Sci 69:1947-1965. CrossRef Medline

Lutz TA, Del Prete E, Szabady MM, Scharrer E (1995) Circadian anorectic effects of peripherally administered amylin in rats. Z Ernahrungswiss 34: 214-219. CrossRef Medline
Lutz TA, Tschudy S, Mollet A, Geary N, Scharrer E (2001) Dopamine D(2) receptors mediate amylin's acute satiety effect. Am J Physiol Regul Integr Comp Physiol 280:R1697-R1703. Medline

Mietlicki-Baase EG, Rupprecht LE, Olivos DR, Zimmer DJ, Alter MD, Pierce RC, Schmidt HD, Hayes MR (2013) Amylin receptor signaling in the ventral tegmental area is physiologically relevant for the control of food intake. Neuropsychopharmacology 38:1685-1697. CrossRef Medline

Moore CX, Cooper GJ (1991) Co-secretion of amylin and insulin from cultured islet beta-cells: modulation by nutrient secretagogues, islet hormones and hypoglycemic agents. Biochem Biophys Res Commun 179: 1-9. CrossRef Medline

Nakamoto H, Soeda Y, Takami S, Minami M, Satoh M (2000) Localization of calcitonin receptor mRNA in the mouse brain: coexistence with serotonin transporter mRNA. Brain Res Mol Brain Res 76:93-102. CrossRef Medline

Ogawa A, Harris V, McCorkle SK, Unger RH, Luskey KL (1990) ) Amylin secretion from the rat pancreas and its selective loss after streptozotocin treatment. J Clin Invest 85:973-976. CrossRef Medline

Oliver KR, Kane SA, Salvatore CA, Mallee JJ, Kinsey AM, Koblan KS, KeyvanFouladi N, Heavens RP, Wainwright A, Jacobson M, Dickerson IM, Hill RG (2001) Cloning, characterization and central nervous system distribution of receptor activity modifying proteins in the rat. Eur J Neurosci 14:618-628. CrossRef Medline

Peciña S, Berridge KC (2005) Hedonic hot spot in nucleus accumbens shell: where do mu-opioids cause increased hedonic impact of sweetness? J Neurosci 25:11777-11786. CrossRef Medline

Potes CS, Lutz TA, Riediger T (2010) Identification of central projections from amylin-activated neurons to the lateral hypothalamus. Brain Res 1334:31-44. CrossRef Medline

Poyner DR, Sexton PM, Marshall I, Smith DM, Quirion R, Born W, Muff R, Fischer JA, Foord SM (2002) International Union of Pharmacology. XXXII. The mammalian calcitonin gene-related peptides, adrenomedullin, amylin, and calcitonin receptors. Pharmacol Rev 54:233-246. CrossRef Medline

Qi D, Cai K, Wang O, Li Z, Chen J, Deng B, Qian L, Le Y (2010) Fatty acids induce amylin expression and secretion by pancreatic beta-cells. Am J Physiol Endocrinol Metab 298:E99-E107. CrossRef Medline

Roth JD, Roland BL, Cole RL, Trevaskis JL, Weyer C, Koda JE, Anderson CM, Parkes DG, Baron AD (2008) Leptin responsiveness restored by amylin agonism in diet-induced obesity: evidence from nonclinical and clinical studies. Proc Natl Acad Sci U S A 105:7257-7262. CrossRef Medline

Roth JD, Maier H, Chen S, Roland BL (2009) Implications of amylin receptor agonism: integrated neurohormonal mechanisms and therapeutic applications. Arch Neurol 66:306-310. CrossRef Medline

Roth JD, Erickson MR, Chen S, Parkes DG (2012) GLP-1R and amylin agonism in metabolic disease: complementary mechanisms and future opportunities. Br J Pharmacol 166:121-136. CrossRef Medline

Rushing PA, Hagan MM, Seeley RJ, Lutz TA, D’Alessio DA, Air EL, Woods SC (2001) Inhibition of central amylin signaling increases food intake and body adiposity in rats. Endocrinology 142:5035. CrossRef Medline

Schochet TL, Bremer QZ, Brownfield MS, Kelley AE, Landry CF (2008) The dendritically targeted protein Dendrin is induced by acute nicotine in cortical regions of adolescent rat brain. Eur J Neurosci 28:1967-1979. CrossRef Medline

Sexton PM, Paxinos G, Kenney MA, Wookey PJ, Beaumont K (1994) In vitro autoradiographic localization of amylin binding sites in rat brain. Neuroscience 62:553-567. CrossRef Medline

Sexton PM, Morfis M, Tilakaratne N, Hay DL, Udawela M, Christopoulos G, Christopoulos A (2006) Complexing receptor pharmacology: modulation of family B G protein-coupled receptor function by RAMPs. Ann N Y Acad Sci 1070:90-104. CrossRef Medline

Singh-Franco D, Perez A, Harrington C (2011) The effect of pramlintide acetate on glycemic control and weight in patients with type 2 diabetes mellitus and in obese patients without diabetes: a systematic review and meta-analysis. Diabetes Obes Metab 13:169-180. CrossRef Medline

Swerdlow NR, Weber M, Qu Y, Light GA, Braff DL (2008) Realistic expecta- 
tions of prepulse inhibition in translational models for schizophrenia research. Psychopharmacology 199:331-388. CrossRef Medline

Turek VF, Trevaskis JL, Levin BE, Dunn-Meynell AA, Irani B, Gu G, Wittmer C, Griffin PS, Vu C, Parkes DG, Roth JD (2010) Mechanisms of amylin/leptin synergy in rodent models. Endocrinology 151:143-152. CrossRef Medline

Ueda T, Ugawa S, Saishin Y, Shimada S (2001) Expression of receptoractivity modifying protein (RAMP) mRNAs in the mouse brain. Brain Res Mol Brain Res 93:36-45. CrossRef Medline

van Rossum D, Ménard DP, Fournier A, St-Pierre S, Quirion R (1994) Autoradiographic distribution and receptor binding profile of [125I]Bolton Hunter-rat amylin binding sites in the rat brain. J Pharmacol Exp Ther 270:779-787. Medline van Rossum D, Hanisch UK, Quirion R (1997) Neuroanatomical localization, pharmacological characterization and functions of CGRP, related peptides and their receptors. Neurosci Biobehav Rev 21:649-678. CrossRef Medline

Young A (2005) Receptor pharmacology. Adv Pharmacol 52:47-65. CrossRef Medline

Young A, Denaro M (1998) Roles of amylin in diabetes and in regulation of nutrient load. Nutrition 14:524-527. CrossRef Medline

Zahm DS, Heimer L (1993) Specificity in the efferent projections of the nucleus accumbens in the rat: comparison of the rostral pole projection patterns with those of the core and shell. J Comp Neurol 327:220-232. CrossRef Medline 